\title{
Use of Habitat and Activity Patterns of Pionus menstruus and Amazona farinosa (Aves: Psitacidae) in a Tropical Dry Forest in Toluviejo, Sucre, Colombia
}

\section{Herrera IM, Sampedro AC*, Jaraba FC and Olmos PM}

Tropical Biodiversity Research Group, University of Sucre, Colombia

*Corresponding author: Alcides C Sampedro Marin, Tropical Biodiversity Research Group, University of Sucre, Colombia, Tel: 57310602 2262; Email: asampedro2002@yahoo.es

\section{Research Article \\ Volume 3 Issue 1}

Received Date: February 01, 2020

Published Date: February 21, 2020

DOI: $10.23880 /$ izab-16000209

\section{Abstract}

To determine the use of the habitat and the patterns of daily activity of two species of psittacids, present in a tropical dry forest in a town in the Montes de María, we make direct observations through point counts, advantageous points and intensive search, in 24 samplings between March and July 2017, between 05:30 and 18:30 hrs. We recorded 421 individuals of Pionus menstruus in 148 sightings and 517 of farmed Amazona in 235 sightings. The largest number of individuals of Pionus menstruus appears in April and May, while the largest number of individuals of Amazona farinosa was observed in July ( $\mathrm{X}=$ 48.26, $\mathrm{p}<0.001,4 \mathrm{df}$ ). The proportion of sightings of these species in zones I and II was similar, but in zone III the number of individuals sighted by $A$. farinosa was much higher than that of P.menstruus (X2 $=44.718, \mathrm{p}<0.001,2 \mathrm{df}$ ). Both species showed greater activity between 0600 and 0700 and between 1600 and 1800, corresponding to lower values of temperature, wind speed and light intensity than those registered at noon. Most of the sightings occurred during flight for both species. To feed, perch, groom and converse, the parrots used 13 species of trees; among them, Amazona farinosa used 11 to perform three or four activities and Pionus menstruus only used six species to perform three of the activities we observed. The frequency of sighted parrots is related to the availability of ecosystem resources, without any evidence of competition between species.

Keywords: Amazona; Montes De Maria; Pionus; Psittacidae; Tropical Dry Forest

\section{Introduction}

Although psittacines can move and cover large areas, they are not evenly distributed among habitats [1,2], being more abundant in those more conserved, with greater availability of resources necessary for their survival and reproduction. Most psittacines employ different adaptive strategies such as diet plasticity, changes in habitat use and movements when adjusting the search for food resources as they follow their availability in the environment [1]. However, the accelerated growth of deforestation activities (including intentional forest fires and selective felling of mature trees) as well as changes in land use [3], are destroying and fragmenting their habitat, thus affecting the different psittacine populations by decreasing the availability of food resources and limiting their nesting opportunities [1]. The Psittacidae family is present in Colombia with 53 species distributed in 17 genera [4]. At present, eleven species are recognized in some category of threat by the International Union for the Conservation of Nature (IUCN). In addition to the reasons mentioned earlier, hunting and looting of nests for the pet market are the greatest pressures on the populations of parrots in the country [5].

Several species of psittacids are reported in the dry tropical forest of the Natural Reserve of the Roca Madre Civil Society, in Montes de María, Sucre and researchers have indicated that the modification of their habitat and 
illegal traffic due to their value as pets, could be affecting populations $[5,6]$. This research can provide information on the use of the habitat and the patterns of daily activity of two species of common parrots in a town of Montes de María, which may contribute to the measures necessary for their conservation.

\section{Materials and Methods}

We carry out this investigation in the village of La Piche, Toluviejo municipality, department of Sucre, Colombia, where the Natural Reserve of the Roca Madre Civil Society (RNSCRM) is located $\left(09^{\circ} 30^{\prime} 44,13\right.$ “ $\mathrm{N}$ and $075^{\circ} 23^{\prime} 50.54$ "W). This reserve is part of the Coraza and Montes de María
Protected Forest Reserve. The area has a total extension of 297 ha and has a tropical dry forest cover (Bs-T) [7] with mountainous areas of medium elevation between 200 and 560 masl [8]. The climate of the region is tropical, influenced by the trade winds, with an average annual temperature of $27.4{ }^{\circ} \mathrm{C}$. The mean rainfall in the year is $1643 \mathrm{~mm}$ with a monthly average of $137 \mathrm{~mm}$ and an average relative humidity of $77 \%[9,10]$. The reserve area is divided into tree study zones, following Geographic Information System technology using a GPS Garmin (Figure 1). Zone I, with an extension of 60.1 ha, zone II, with 40.6 ha and zone III with 41 ha, for a total of 141.7 ha. We did 24 field trips, between March and July 2017, between 05:30 and 18:30 hours.

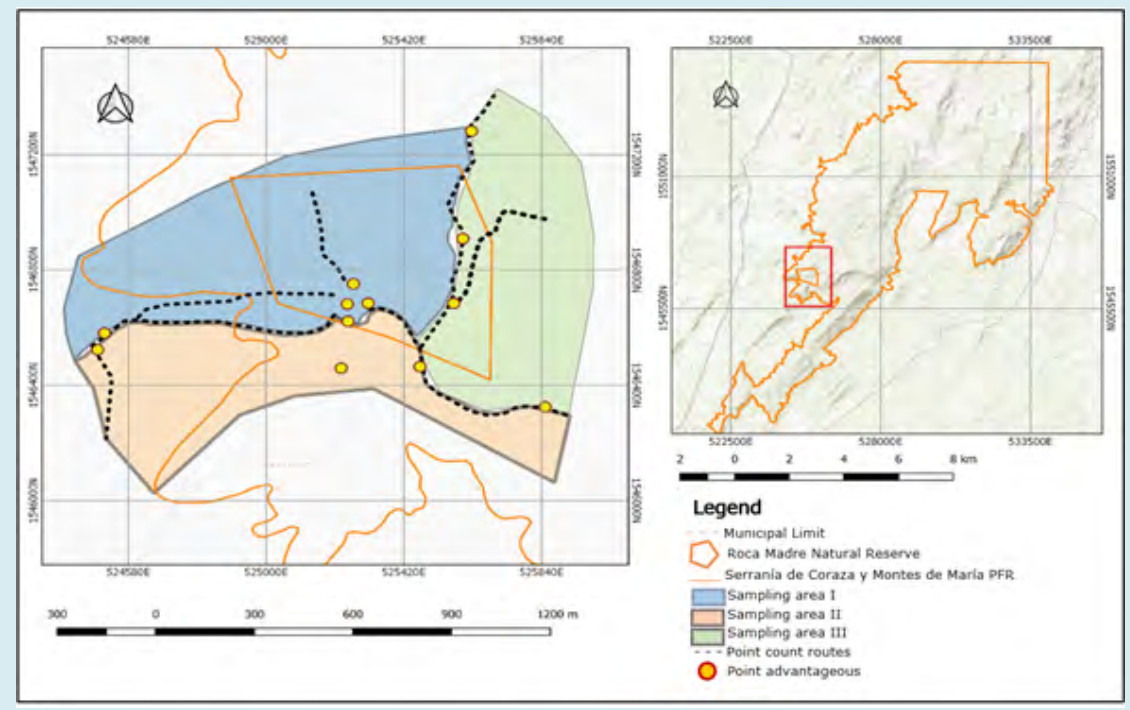

Figure 1: Geographic location of sampling areas within and around the RNSC Roca Madre.

Sampling consisted of direct observations using combinations of three methods, point counts and intensive search counts and the method of advantageous points each with duration of 20 minutes. We report all the birds observed and heard belonging to the two species under study [11,12]. We write down their location within the area, as was the stratum they occupied at the time sighting (canopy, high stratum branch, middle stratum branch), the activity they were performing $(\mathrm{A}=$ feeding, $\mathrm{P}=$ hanger, $\mathrm{Ac}=$ grooming, $\mathrm{Pt}=$ chatting), the number of individuals, the hour of activity and the social organization in which they were (alone, couple, group).

Observations were made using Vanguard 10x50 binoculars and the photographic evidence, was obtained using a professional Canon Powershot 60X camera. We marked the trees used by the birds with enamel, listed according to the area where we found them. We also measure the diameter at chest height (DCH) (tape measure) and height (Abney level). We identify trees "in situ" and in case of doubt, we take samples were for their subsequent identification, through the application of taxonomic keys and consultation with experts in the Conservation Laboratory of the University of Sucre [13].

We take measurements of temperature and relative humidity (thermo hygrometer KTJ TA 318), wind speed (Holdpeak anemometer HP 866B) and light intensity (TASI TA8132 luxmeter), three times a day (morning, noon and afternoon). We measured precipitation (Toland rain gauge), at the beginning and at the end of the daily sampling [11]. We calculated the relative abundance using the frequency of sightings as a criterion, that is, the total number of samplings in which we observe the bird, in relation to the total samplings made. We interpret as follows: abundant (A): (70100\%), common (C): (51-69\%) and poorly observed (PO): ( $\leq$ $50 \%$ ). We measured the monthly abundance of each species 
as the average number of individuals detected per unit of effort, that is, by days in the field (sampling) every month (6 days). We made a square-chi test ( $\mathrm{X}^{2} \mathrm{ut}$ for the comparison of abundances, social organization and frequency of use of the substrates between the zones and the months of sampling. We use the Jacard index to determine the similarity between the three study zones, for the tree species used by the parrots.

\section{Results}

In the 24 samplings (eight per zone) made between March and July 2017, we register 421 blue-headed parrots (P. menstruus) in 148 sightings in the different work zones $(\mathrm{ZI}=202, \mathrm{ZII}=151$ and ZIII $=68)$, and 517 individuals of the mangrove parrot (A. farinosa) in 235 sightings (ZI: 217; ZII: 121; ZIII: 179). Both species were abundant (A) (Figure 2).

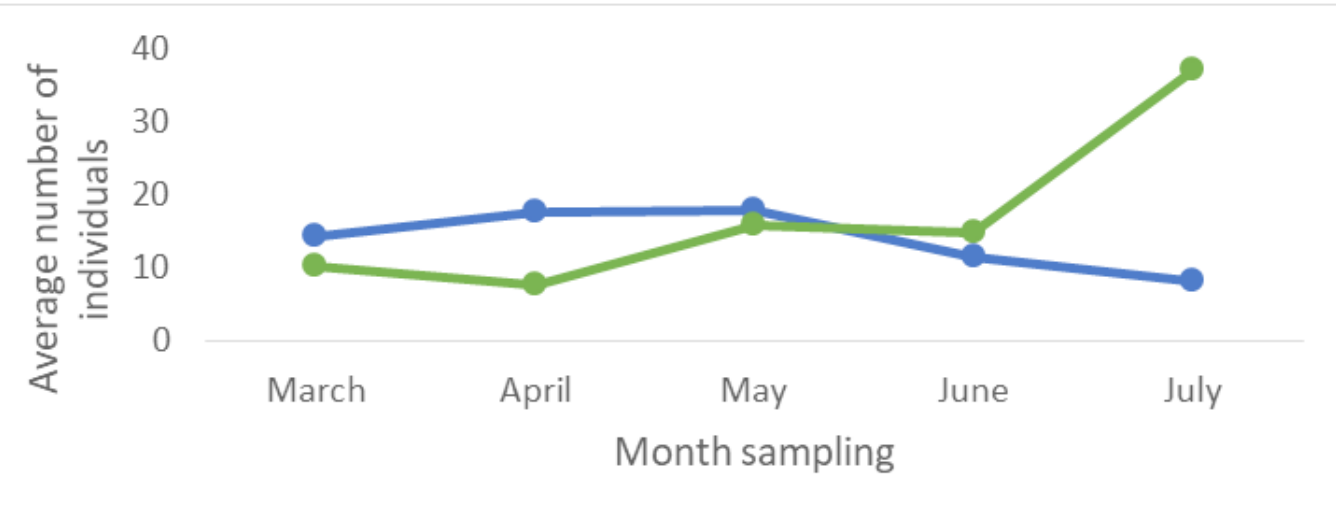

\section{Pionus menstruus $\longrightarrow$ Amazona farinosa}

Figure 2: Average number of $P$. menstruus and A. farinosa, sighted in 5 months of samplings, in a locality of Montes de María.

In Figure 2 it can be seen that the proportion of sightings of $P$. menstruus in April and May, and that of A. farinosa in July, was significantly greater in relation to the other months of sampling $\left(\mathrm{X}^{2}=48.26, \mathrm{p}<0.001 ; 2 \mathrm{df}\right)$. The proportion of sightings of these species in zones I and II was similar (Figure 3), but in zone III the number of individuals sighted by $A$. farinosa was much higher than that of P.menstruus. $\left(\mathrm{X}^{2}\right.$ $=44.718, \mathrm{p}<0.001 ; 2 \mathrm{df}$ ).

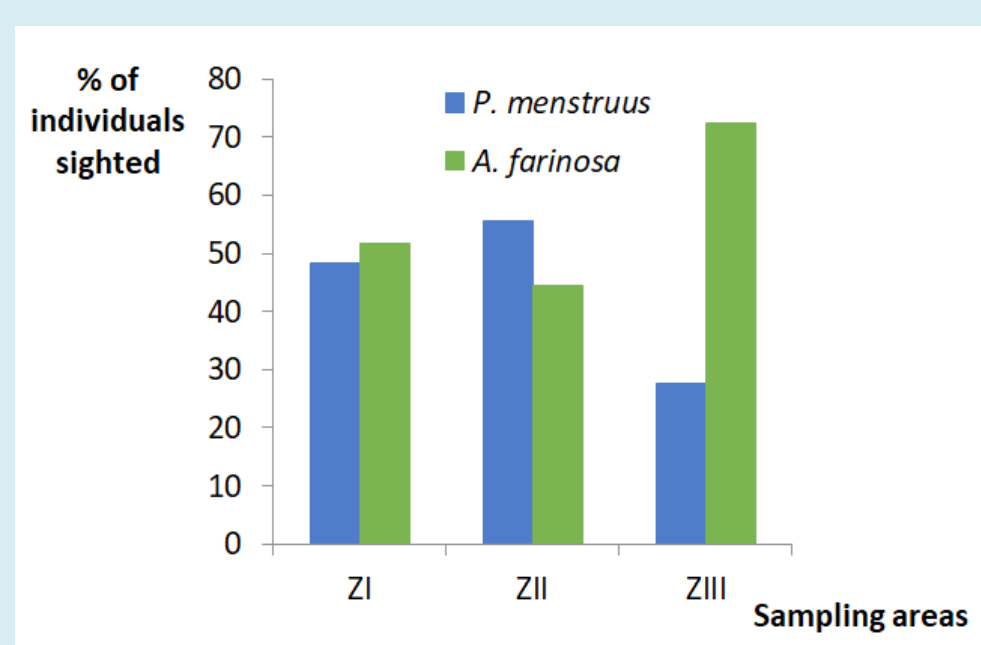

Figure 3: Proportion of individuals of $P$. menstruus and A. farinosa, sighted in the three study areas.

We find a highly significant association between the species, and the social organization presented by the individuals, at the time we sighted them $\left(\mathrm{X}^{2}=43.69, \mathrm{p}\right.$ $<0.001,2 \mathrm{df}$ ). P. menstruus was observed mostly in pairs or 
as a group, whereas A. farinosa appeared more frequently as

a pair (Figure 4).

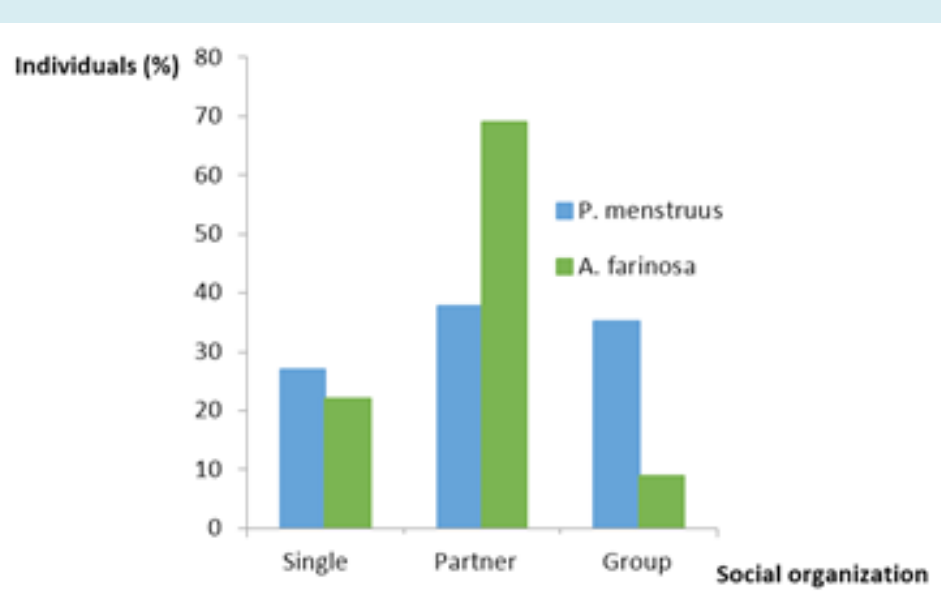

Figure 4: Proportion of individuals of $P$. menstruus and A. farinosa in different types of social organization.

The same analysis for the sampling months showed that P. menstruus presents a significant association of the social organization with the months of sighting $\left(\mathrm{X}^{2}=22.23, \mathrm{p}<\right.$ 0.05; $8 \mathrm{df}$ ). In March, we observed a significant number of couples. For the other forms of social organization, we do not appreciated a well-defined trend. A. farinosa does not present an association of it social organization with the months of sighting $\left(\mathrm{X}^{2}=8.05, \mathrm{p}>0.05: 8 \mathrm{gl}\right)$, however, there is a tendency for the species to appear as a couple in the months of May, June and July (Figure 5).

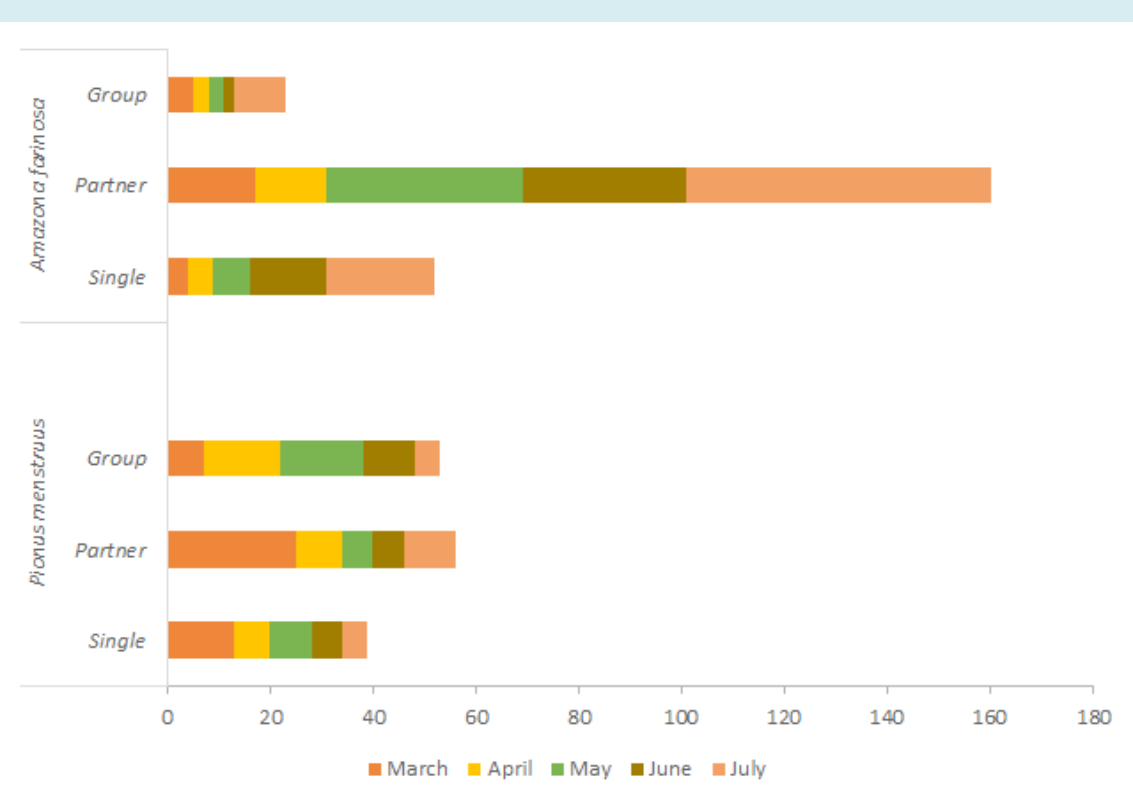

Figure 5: Proportion of individuals with different social organization observed during the sampling months for the two species under study.

Both species showed greater activity between 0600 and 0700 and between 1600 and 1800 (Figure 6), corresponding to lower values of temperature, wind speed and light intensity than those registered at noon (Figure 7). In the intermediate hours, between 1000 and 1400 very few individuals are observed 


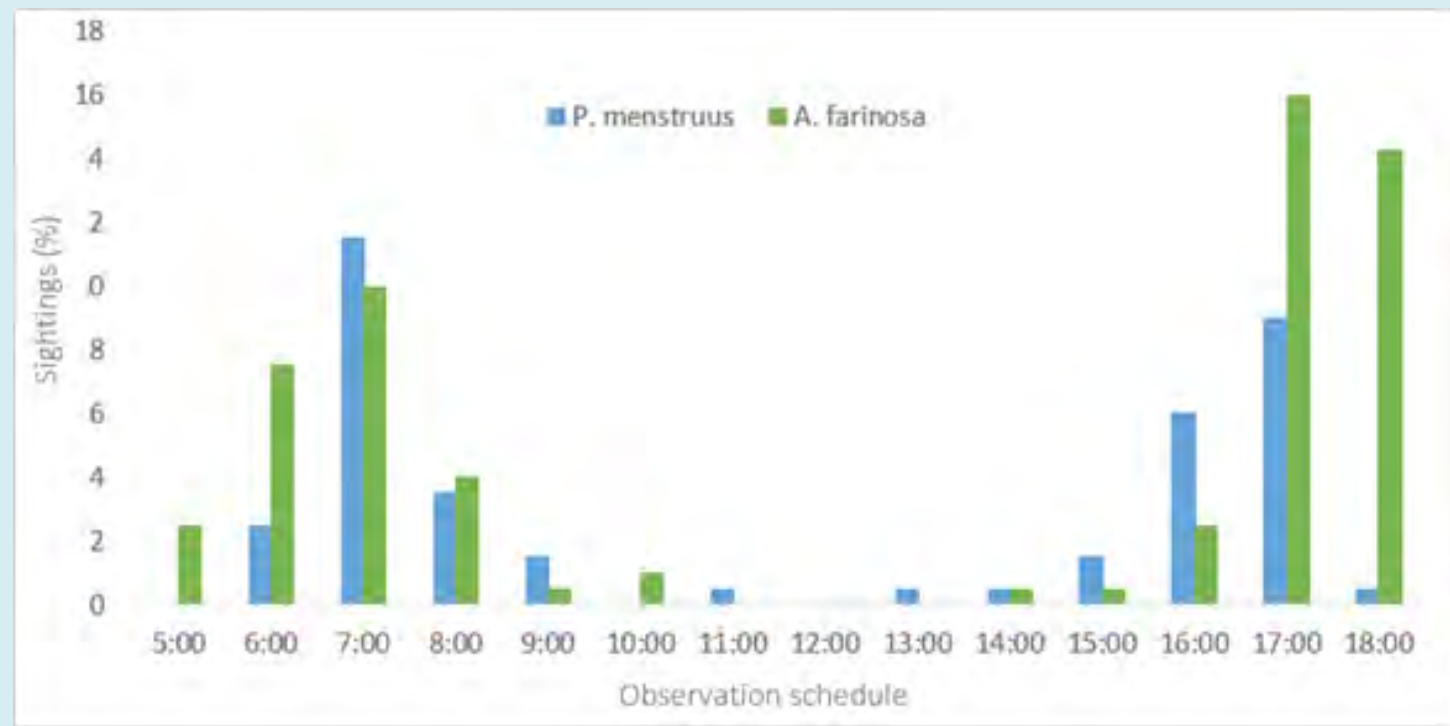

Figure 6: Proportion of individuals of $P$. menstruus and A. farinosa sighted every hour between 05:00 and 18:00 in five months of sampling in the study area.

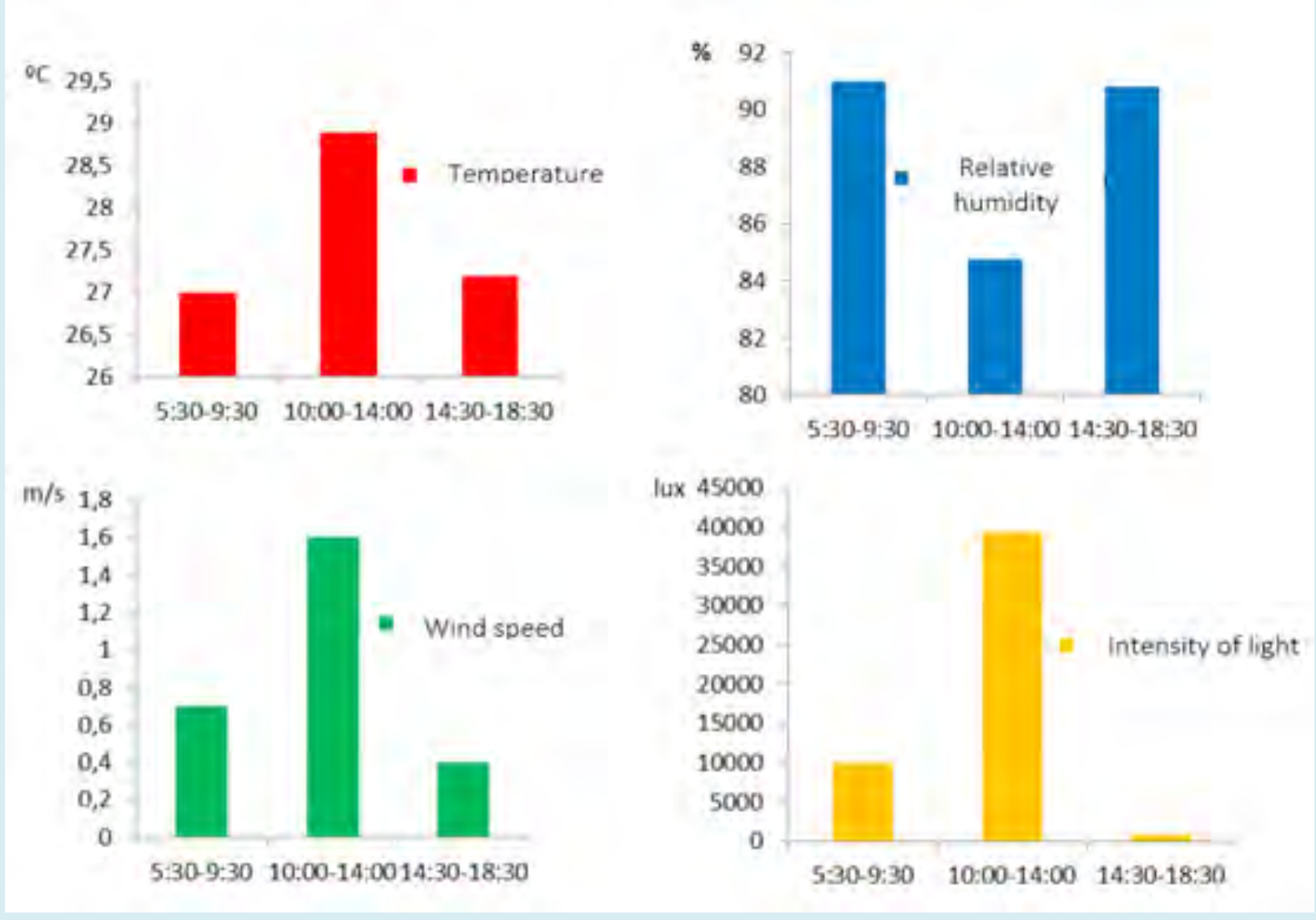

Figure 7: Average climatic conditions measured in three time ranges during the day for the 24 samplings made. 
There was a tendency to decreased activity, measured as the number of sightings, for both species during rainy days,

which were only seven (Figure 8).

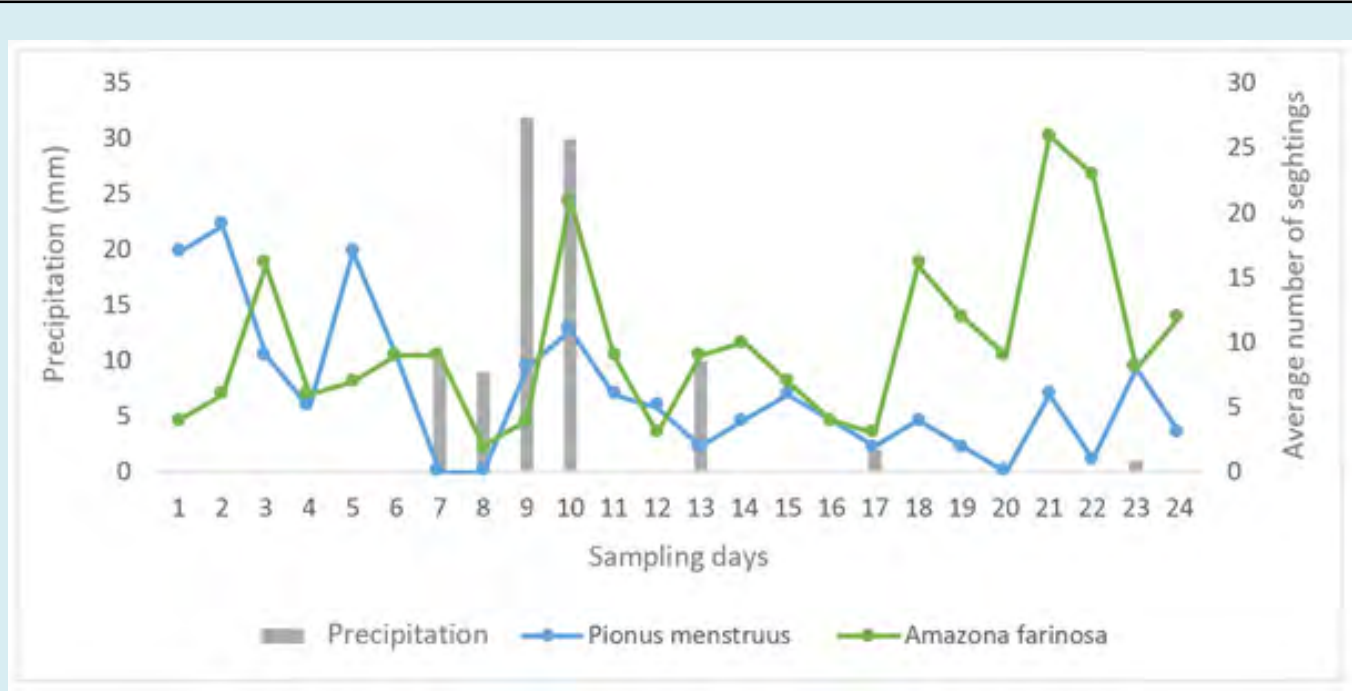

Figure 8: Average number of sightings of $P$. menstruus and $A$. farinosa in dry and rainy days, during the 24 days of sampling in the study area.

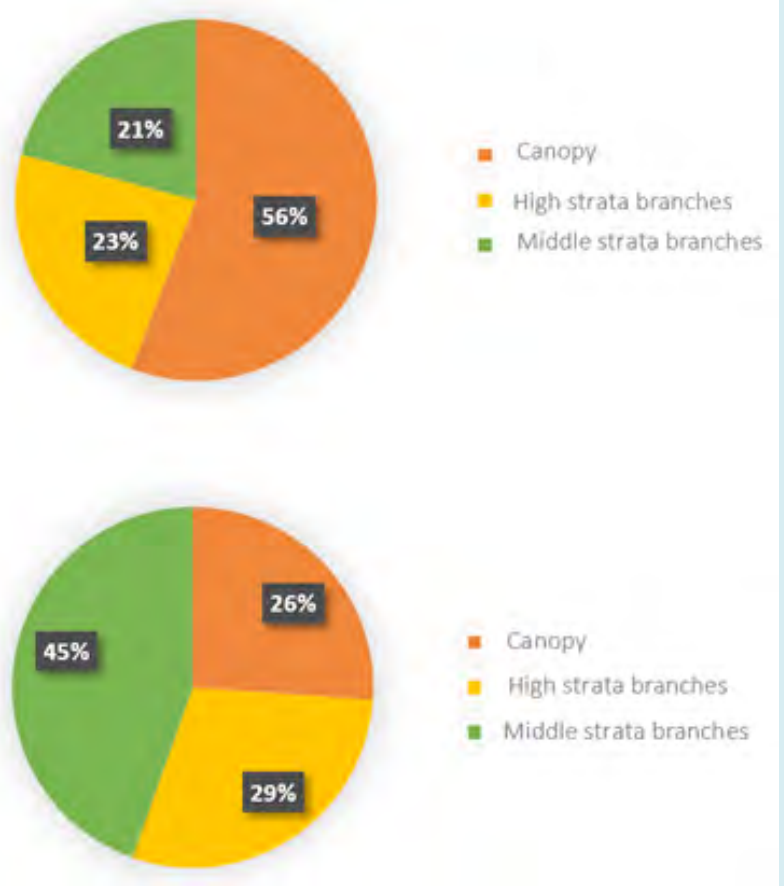

Figure 9: Proportion of individuals of the species $P$. menstruus (top) and $A$. farinosa (bottom) sighted using different substrates in the study location.
On dry days an average of 7.6 sightings of $P$. menstruus were recorded, while on rainy days an average of 3.7 were recorded; similarly, for $A$. farinosa an average of 10 sightings were recorded on dry days, while on rainy days the average was 7.

Most sightings occurred during flight for species, $72.5 \%$ for $P$. menstruus, $61.07 \%$ for $A$. farinosa. The rest of the individuals appeared in the arboreal substrate, using the canopy, the branches of the high and medium strata (Figure 9). We obtained a significant association between the number of individuals of both species and the substrate they used when sighted $\left(\mathrm{X}^{2}=4.907, \mathrm{p}<0.001,2 \mathrm{df}\right)$. This is because, although both species frequently use the different strata, $P$. menstruus was found mostly in the canopy, and $A$. farinose, in the upper branches.

The blue-headed parrot used 11 tree species belonging to six families (Anacardeaceae, Lauraceae, Fabaceae, Malvaceae, Meliaceae, and Moraceae). The Moraceae family presented the largest number of species used by P. menstruus. The mangrove parrot used 20 tree species belonging to 11 families (Anacardeaceae, Burseraceae, Cecropiaceae, Euphorbiaceae, Hernandiaceae, Fabaceae, Malvaceae, Meliaceae, Moraceae, Polygonaceae, Sapindaceae) and the Fabaceae family presented the largest number of species used by A. farinose (Table1). 


\section{International Journal of Zoology and Animal Biology}

\begin{tabular}{|c|c|c|c|c|}
\hline Family & Scientific Name & Common Name & P. menstruus & A. farinosa \\
\hline & Astronium graveolens & Santa Cruz & $\mathrm{A}, \mathrm{P}, \mathrm{Pt}$ & $\mathrm{P}, \mathrm{Ac}, \mathrm{Pt}$ \\
\hline Anacardeaceae & Spondias mombin & Jobo & A, P & $\mathrm{A}, \mathrm{P}, \mathrm{Ac}, \mathrm{Pt}$ \\
\hline Burseraceae & Bursera simaruba & Indio encuero & & $\mathrm{P}, \mathrm{Pt}$ \\
\hline Cecropiaceae & Cecropia obtusifolia & Guarumo & & $\mathrm{P}, \mathrm{Ac}, \mathrm{Pt}$ \\
\hline Euphorbiaceae & Hura crepitans & Ceiba de leche & & $\mathrm{P}, \mathrm{Ac}, \mathrm{Pt}$ \\
\hline Hernandiaceae & Undetermined Sp 1 & & & $\mathrm{P}, \mathrm{Pt}$ \\
\hline \multirow{4}{*}{ Lauraceae } & Persea americana & Aguacate & $\mathrm{P}, \mathrm{Ac}, \mathrm{Pt}$ & \\
\hline & Albizia guachapele & Campano & & $\mathrm{A}, \mathrm{P}, \mathrm{Ac}, \mathrm{Pt}$ \\
\hline & Albizia niopoides & Guacamayo & $\mathrm{A}, \mathrm{P}, \mathrm{Pt}$ & $\mathrm{P}, \mathrm{Pt}$ \\
\hline & Albizia sp. & Chicho & $\mathrm{A}$ & \\
\hline \multirow{3}{*}{ Fabaceae } & Caesalpinia parahyba & Tambolero & & $\mathrm{P}, \mathrm{Pt}$ \\
\hline & Enterolobium cyclocarpum & Orejero & & $\mathrm{P}, \mathrm{Pt}$ \\
\hline & Peltogynea purpurea & Brasil & & $\mathrm{P}, \mathrm{Ac}, \mathrm{Pt}$ \\
\hline \multirow{2}{*}{ Malvaceae } & Pseudobombax septenatum & Majagua & $\mathrm{P}, \mathrm{Pt}$ & $\mathrm{P}, \mathrm{Pt}$ \\
\hline & Ochroma pyramidale & Balso & & $\mathrm{P}, \mathrm{Pt}$ \\
\hline \multirow[t]{2}{*}{ Meliaceae } & Cedrela odorata & Cedro & $\mathrm{P}$ & $\mathrm{P}, \mathrm{Ac}, \mathrm{Pt}$ \\
\hline & Brosimum alicastrum & Guáimaro & A, P, Ac & $\mathrm{A}, \mathrm{P}, \mathrm{Ac}, \mathrm{Pt}$ \\
\hline \multirow[t]{2}{*}{ Moraceae } & Ficus dendrosida & Suan & A, P, Ac & $\mathrm{A}, \mathrm{P}, \mathrm{Ac}, \mathrm{Pt}$ \\
\hline & Undetermined Sp. 2 & Cabo de Hacha & $\mathrm{P}$ & \\
\hline Polygonaceae & Triplaris americana & Vara Santa & & $\mathrm{P}$ \\
\hline \multirow{3}{*}{ Sapindaceae } & Melicoccus bijugatus & Mamón & & $\mathrm{A}, \mathrm{P}, \mathrm{Ac}, \mathrm{Pt}$ \\
\hline & Undetermined Sp. 3 & Árbol seco & $\mathrm{P}, \mathrm{Ac}, \mathrm{Pt}$ & $\mathrm{P}, \mathrm{Ac}, \mathrm{Pt}$ \\
\hline & Undetermined Sp. 4 & Zapato & & $\mathrm{P}, \mathrm{Pt}$ \\
\hline
\end{tabular}

Table 1: indicates the tree species where the two species of parrots under study and the activity they were performing at that site when sighted.

\begin{tabular}{|c|c|c|c|}
\hline \multicolumn{5}{|c|}{ P. menstruus } \\
\hline & Zona 1 & Zona 2 & Zona 3 \\
\hline Zone 1 & - & 0 & $12.50 \%$ \\
\hline Zone 2 & & - & 0 \\
\hline Zone 3 & & & - \\
\hline \multicolumn{4}{|c|}{ A. farinosa } \\
\hline Zone 1 & - & $19 \%$ & $14.20 \%$ \\
\hline Zone 2 & & - & $12 \%$ \\
\hline Zone 3 & & & - \\
\hline
\end{tabular}

Table 2: Matrix of similarity (Jaccard index) between the three study zones for tree species used by P. menstruus and A. farinosa.

There is no overlap in the type of trees used by both species in the three zones. The Jaccard index was $37.5 \%$ (Table 2) because only nine tree species were not commonly used by parrots.

The eleven tree species used by $P$. menstruus are distributed among the three zones studied. In zone I, blueheaded parrots were recorded in Espondias mombin, Persea americana, Albizia neipoideis, Cedrela odorata, Brosimum alicastrum and an indeterminate species; in zone II, records were made on Albizia sp., Pseudobombax septenatum, Ficus dendrosida and an indeterminate species. In zone III, the species was spotted in Astronium graveolens, Brosimum alicastrum and an indeterminate species.

The mangrove parrot use 20 species of trees, distributed among the three zones. In zone I use Astronium graveolens, Espondias mombin, Bursera simaruba, Cecropia obtusifolia, Ochroma pyramidale, Cedrela odorata, Brosimum alicastrum, 
Triplaris americana, and two indeterminate species; in zone II, use Astronium graveolens, Albizia guachapele, Albizia neipoides, Caesalpinia parahyba, Enterollobium cyclocarpum, Pseudobombax septenatum, Ochroma pyramidale, Cedrela odorata, Ficus dendrosida, Triplaris americana, Melicoccus bijugatus, and two indeterminate species and in zone III use Astronium graveolens, Cecropia obtusifolia, Hura crepitans, Ficus dendrosida, and two indeterminate species.
We observe the behavior of parrots in 13 tree species (Table 3). Of those 13, A. farinosa uses 11 to perform three or four activities and P. menstruus only uses six species to perform three of the observed activities. The trees used by the two species of parrots to carry out three or four activities were Astronium graveolens (Santa Cruz), Brosimum alicastrum (Guaimaro), Ficus dendrosida (Suan) and the indeterminate Sp 4.

\begin{tabular}{|c|c|c|c|}
\hline Scientific Name & Common Name & Pionus menstruus & Amazona farinosa \\
\hline Astronium graveolens & Santa Cruz & $\mathrm{A}, \mathrm{P}, \mathrm{Pt}$ & $\mathrm{P}, \mathrm{Ac}, \mathrm{Pt}$ \\
\hline Spondias mombin & Jobo & $\mathrm{A}, \mathrm{P}, \mathrm{Ac}, \mathrm{Pt}$ \\
\hline Cecropia obtusifolia & Guarumo & & $\mathrm{P}, \mathrm{Ac}, \mathrm{Pt}$ \\
\hline Hura crepitans & Ceiba de leche & & $\mathrm{P}, \mathrm{Ac}, \mathrm{Pt}$ \\
\hline Persea americana & Aguacate & $\mathrm{P}, \mathrm{Ac}, \mathrm{Pt}$ & $\mathrm{A}, \mathrm{P}, \mathrm{Ac}, \mathrm{Pt}$ \\
\hline Albizia guachapele & Campano & & $\mathrm{Pt}, \mathrm{Ac}, \mathrm{Pt}$ \\
\hline Albizia niopoides & Guacamayo & $\mathrm{A}, \mathrm{P}, \mathrm{Pt}$ & $\mathrm{P}, \mathrm{Ac}, \mathrm{Pt}$ \\
\hline Sp. Indeterminada 2 & Brasil & $\mathrm{A}, \mathrm{P}, \mathrm{Ac}, \mathrm{Pt}$ \\
\hline Cedrela odorata & Cedro & $\mathrm{P}$ & $\mathrm{P}, \mathrm{Ac}, \mathrm{Pt}$ \\
\hline Brosimum alicastrum & Guáimaro & $\mathrm{A}, \mathrm{P}, \mathrm{Ac}$ & $\mathrm{A}, \mathrm{P}, \mathrm{Ac}, \mathrm{Pt}$ \\
\hline Ficus dendrosida & Suan & $\mathrm{A}, \mathrm{P}, \mathrm{Ac}$ & $\mathrm{P}, \mathrm{Ac}, \mathrm{Pt}$ \\
\hline Melicoccus bijugatus & Mamón & $\mathrm{P}, \mathrm{Ac}, \mathrm{Pt}$ \\
\hline Sp. Indeterminada 4 & árbol seco & & \\
\hline
\end{tabular}

Table 3: Species of trees in which the parrots of both species under study carried out three or four activities. $(A=$ Feeding, $P=$ perching, $\mathrm{Ac}=$ Grooming, $\mathrm{Pt}=$ Chatting).

The frequency of each type of activity in the trees (Figure 10) was very similar for both parrots. Perching was the most

frequently observed activity.

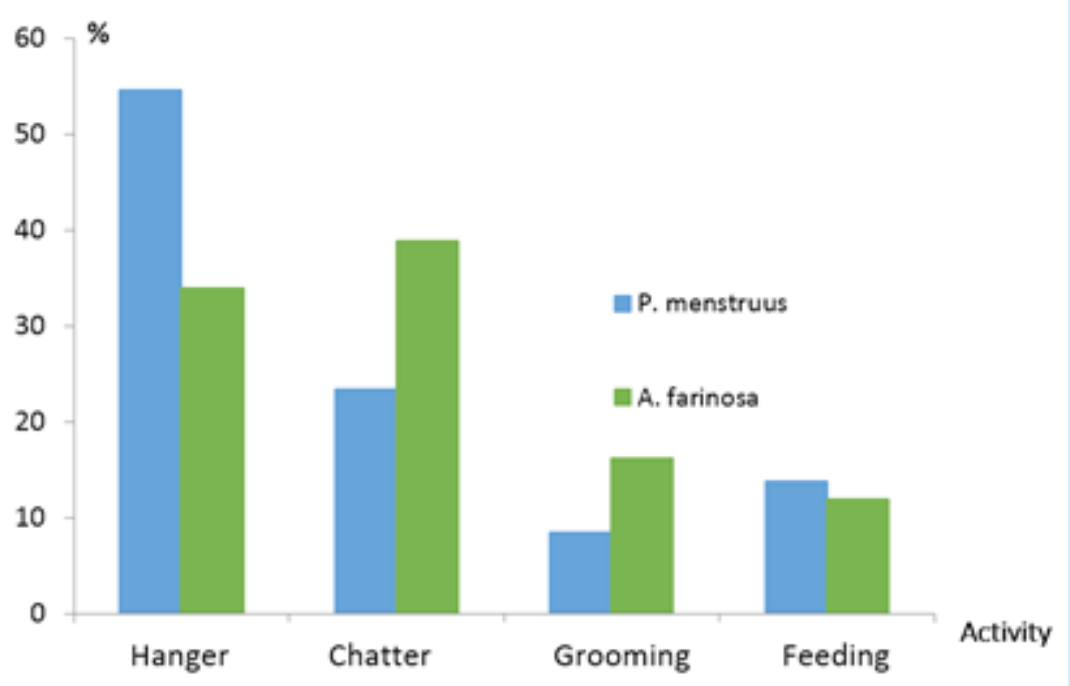

Figure 10: Proportion of individuals engaged in each activity for each parrot species in the trees visited by them in the study area. 
The blue-headed parrot used six species of trees to feed, while the mangrove parrot used five (Table 4). The common species used by them were jobo, guáimaro and Suan, with similarity index of $37.5 \%$.

\begin{tabular}{|c|c|c|c|}
\hline Scientific Name & Common Name & P. menstruus & A. farinosa \\
\hline Astronium graveolens & Santa Cruz & X & X \\
\hline Spondias mombin & Jobo & X & X \\
\hline Albizia guachapele & Campano & - & - \\
\hline Albizia niopoides & Guacamayo & X & - \\
\hline Albizia sp. & Chicho & X & X \\
\hline Brosimum alicastrum & Guáimaro & X & X \\
\hline Ficus dendrosida & Suan & - & $\mathrm{X}$ \\
\hline Melicoccus bijugatus & Mamón & & \\
\hline
\end{tabular}

Table 4: Species of trees where individuals of $P$. menstruus and $A$. farinosa were observed feeding.

\section{Discussion}

The high number of sightings of P.menstruus and $A$. farinosa in this locality suggests the presence of a considerable population of both species. The fact that they are inside a protected area has guaranteed the good state of conservation of this relic of tropical dry forests, ensuring the availability of resources for the presence and development of these species of parrots in the area. However, the threats persist, since very close to the area there is habitat fragmentation due to limestone extraction activities, illegal trafficking of parrot species, logging and forest burning for the establishment of crops, as could be appreciated during the development of the investigation.

The differences in the abundance of both species in the different sampling months, could be related to different breeding seasons, which could decrease the competition for food resources during this stage. The breeding season for $P$. menstruus usually begins from May to June and runs until September [14], while the breeding season of $A$. farinosa spans from March to April until the beginning of July coinciding with the months in which the samplings were made [15].

The frequency of differential sighting seen in the three sampling zones, especially in zone III, can have two explanations. One, is related to potential counting errors: A. farinosa performs a loud chatter, and when a large number of individuals are perched in the canopy, their noisy vocalizations make it difficult to detect more silent species. The other possible explanation is the difference in the movements that these species execute in these areas. $A$. farinosa performs short flights between the three zones of study, while the movements of $P$. menstruus are projected mostly out of the study area, in the direction of crops, as could be verified. This suggests little competition between these two species, in relation to their distribution within the area. A. farinosa is a much more restricted species to extensive areas of conserved tropical evergreen forest, which makes it difficult to detect in intervened or cultivated forests, since these conditions do not meet its ecological requirements [16]. P. menstruus, is frequently observed in disturbed forest habitats, in areas of abandoned crops under regeneration, in ecotones, and in cultivated lands $[17,18]$.

The phase outside of the reproductive period also seems to influence the differences observed in their social behavior. A. farinosa has few outings as a couple during incubation, because one of the parents assumes the incubation task and the outputs are very short [15]. As the breeding period progresses, a greater frequency of departures of the couple is observed. They spend longer times in the foraging and feeding activities and in the final stage of the feathering of the chicks, the outputs in pairs increase significantly, going backwards and forwards from the nest, making short flights around the nesting area. P. menstruus can be found alone [14], but it is a very sociable species and is usually observed in small groups of eight, twelve to fifteen or more individuals. However, during the breeding season it tends to fly in pairs or separately $[14,19,20]$.

The drier and hotter conditions that usually prevail around noon in the dry season probably influence the decrease in sightings $[14,21]$. The parental care in the early hours of the morning and late afternoon also influence the higher number of sightings [16]. Both species coincide in this activity schedule $[14,15,20,22]$; however $A$. farinosa remains much more active than $P$. menstruus during the day and is observed more frequently on dry and rainy days, which could be related to greater energy requirements by this species.

Many of the trees used by both species are also used by these parrots in other departments of Colombia, such as 
Antioquia [22], and even in different countries, such as Brazil and Nicaragua $[15,20,23]$. It has been suggested that it is common for differentspecies of psittacines to occupy the same trees to where they feed themselves, and that aggressions usually do not occur between them [23]. However, in the present investigation, it was shown that $A$. farinossa and $P$. menstruus use different plants to feed, and do it at different heights. This seems to be another mechanism that decreases competition between these species. It is possible that the difficulty in detecting these species during feeding, could influence this appreciation and perhaps it is also the reason that they are observed more frequently developing other activities, especially perching and chattering.

\section{Conclusion}

In the Roca Madre Civil Society Reserve, there are the necessary resources that guarantee the presence of $P$. menstruus and A. farinosa in that locality. There is evidence of ecological mechanisms that allow this sympatry, such as the non-coincidence of the reproductive periods, the performance of similar activities, but using different tree species, and at different heights, and the shorter time of permanence of one of the species in that area.

\section{References}

1. Parra Martinez SM, De Labra Hernandez MA, Renton K (2016) Requerimientos ecológicos en las aves: un enfoque en psitácidos. Tópicos sobre ciencias biologicas. Universidad de Guadalajara Centro Universitario de la Costa, pp: 33-60.

2. Rubio Y, Avilez F, Guerrero C (2010) Avances de la ecología y conservación de Psitácidos en Sinaloa, México, pp: 479-487.

3. De Labra MA, Escalante P, Monterrubio Rico TC, Coates Estrada R (2010) Hábitat, abundancia y perspectivas de conservación de psitácidos en la Reserva de los Tuxtlas, Veracruz, México. Ornitología Neotropical 21: 599-610.

4. Rodriguez Mahecha JV, Hernandez Camacho JI (2002) Loros de Colombia. Conservación Internacional. Bogotá.

5. Rodriguez Mahecha JV, Suarez FR, Arzuza DE, Hernandez AG (2005) Loros, pericos y guacamayas neotropícales. Conservación internacional. Panamericana, Bogotá D.C, pp: 148.

6. Sampedro A, Alvarez A, Dominguez L, Herrera I (2013) Especies promisorias para el ecoturismo en "Campo Aventura Roca Madre", Toluviejo-Sucre, Colombia. Rev. MVZ Córdoba 18(1): 3387-3398.

7. (2017) Ministry of Environment and Sustainable
Development. National Natural Parks of Colombia.

8. Vasquez V (2005) Reservas Forestales Protectoras Nacionales de Colombia, Atlas Básico. Conservación Internacional Colombia; Ministerio de Ambiente, Vivienda y Desarrollo Territorial, pp: 123.

9. Carsucre (2016) Plan de Acción Institucional 20162019, pp: 212.

10. Rangel Ch JO, Carvajal Cogollo JE (2012) Climate of the Colombian Caribbean Region. The Caribbean region of Colombia, pp: 1046.

11. Ralph CJ, Geupel G, Pyle P, Martin TE, Desante DF, et al. (1996) Manual de métodos de campo para el monitoreo de aves terrestres. General Technical Report. Pacific Southwest Research Station. Forest Service. U.S. Departament of Agriculture pp: 46.

12. Bibby C, Jones M, Marsden S (1998) Expedition Field Techniques Bird Surveys. Expedition Advisory Centre -Royal Geographical Society. London pp: 143.

13. Gentry A (1993) A field guide to the families and genera of woody plants of Northwest South American. Economic Botany pp: 895.

14. Roth P (1984) Reparticao do hábitat entre psitacideos simpátricos no sul da Amazónia. Acta Amazónica 14(12): 175-221.

15. Bjork RD (2005) Seasonal abundance and habitatuse patterns of parrots in Guatemala using a canopybased survey method to estimate density. Oregon State University pp: 74-212.

16. Renton K (2001) Lilac-crowned parrot diet and food resource availability: resource tracking by a parrot seed predator. The Condor 103: 62-69.

17. Johns (1991) Responses of Amazonian rain forest birds to hábitat modification. Journal of Tropical Ecology 7(4): 417-437.

18. Pacheco JF, Olmos F (2005) Birds of a latitudinal transect in the Tapajós-Xingu interfluvium, Eastern Brazilian Amazonia. Ararajuba 3(1): 29-46.

19. Rodriguez Mahecha JV, Rueda Almonacid JV, Gutierrez TD (2008) Guía ilustrada de la fauna del Santuario de Vida Silvestre Los Besotes, Valledupar, Cesar, Colombia. Serie de guías tropicales de campo $\mathrm{n}^{\circ} 7$, Conservación Internacional-Colombia. Editorial Panamericana, Formas e Impresos. Bogotá, Colombia pp: 574 .

20. Galetti (1992) Comparative Seed Predationo on Pods by 
Parrots in Brazil. Biotropica 24(2a): 222-224.

21. Blake JG (1992) Temporal variation in point of birds in a lowland wet forest in Costa Rica. Condor 94(1): 265-275.

22. Arango A (2008) Caracterización de poblaciones de Psitácidos en el valle de Aburra-Antioquia. Medellín,
Colombia: “CORANTIOQUIA" Corporación Autónoma Regional del Centro de Antioquia.

23. Simao IFA, Maes Dos Santos YM, Pizo A (1997) Vertical stratification and diet of psittacids in a Tropical lowland forest of Brazil. Ararajuba 5(2): 169-174. 